\title{
REPUTATION AND THE ORGANIZATION
}

Personal Reputation and the Organization

Robert Zinko and Mark Rubin

The University of Newcastle, Australia

This self-archived version is provided for non-commercial and scholarly purposes only.

The APA $\left(6^{\text {th }}\right.$ ed $)$ style reference for this article is as follows:

Zinko, R., \& Rubin, M. (2015). Personal reputation and the organization. Journal of Management and Organization, 21, 217-236. doi: 10.1017/jmo.2014.76

Correspondence concerning this article should be addressed to: Robert Zinko, College of Business and Law, University of Newcastle, NSW, Australia, 2203 robert.zinko@newcastle.edu.au 


\title{
REPUTATION AND THE ORGANIZATION
}

\begin{abstract}
Drawing from fields such as marketing psychology, strategy, social psychology, and organizational behavior, the present examination explores the individual and organizational bases for personal reputation; specifically, how different bases interact with one another to produce an individual's reputation within organizations. It is proposed that individuals use personal reputations to satisfy their need for positive self-esteem as well as to secure their sense of belonging in organizations. Furthermore, reputation allows individuals to obtain rewards such as autonomy, power, and career success and the opportunity to signal key information to audiences. Likewise, organizations utilize personal reputations to predict their members' behaviors, market those who are a part of the organization to others, build their own corporate reputations, and signal information to consumers and competitors. To further this understanding of personal reputation an examination is presented as to how organizations serve as an essential context within which individuals realize their personal reputations and regulate their behavior.
\end{abstract}

Keywords: personal reputation, reputation; self-presentation; gossip; signaling 


\section{Introduction}

Over the last decade, a body of knowledge has developed that examines why individuals and organizations may wish to create positive reputations (e.g., Hall, Zinko, Perryman, \& Ferris, 2009; Laird, Perryman, Hochwarter, Ferris, \& Zinko, 2008; Laird, Zboja, Martinez, \& Ferris, 2013; Zinko, 2013; Zinko, Gentry, Hall, \& Grant, 2012). Research has suggested that the outcomes of possessing a positive reputation have such valuable benefits, that both organizations as well as individuals often devote a substantial amount of resources to the matter (Ferris, Blass, Douglas, Kolodinsky, \& Treadway, 2003; Gray \& Balmer, 1998). Indeed, at the organizational level, corporations that develop positive reputations often enjoy rising stock prices, the attraction of talented employees, and an increase in customers (Roberts \& Dowling, 2002). Likewise, at the individual level, personal reputation has been shown to be linked to power, career advancement, autonomy, and several other positive results (Zinko, Ferris, Humphrey, Meyer, \& Amie, 2012). Although our knowledge is advancing in both the areas of individual and organizational reputation, we have yet to fully understand the effects that individuals' reputations may have on organizations. That is to say, both corporate as well as personal reputation scholars acknowledge the value of organizations possessing individuals with definitive reputations, but to date no existing theory ties the development of personal reputation and its benefits to that of the organization.

It is this disconnect in the literature between those building a reputation and the organizations of which they are a part that this study aims to address. This is not done in an attempt to develop a separate, alternative theory as to how personal reputations operate; but rather to show how current, overlapping theories combine and interact, in a unifying manner. To accomplish this task, we draw on several different fields of research in order to propose a model that relates existing theories and empirical findings.

\section{Plan of Study}

In an effort to view the construct in a more robust, contextual manner, this article explores personal reputation by examining not only the paradigm that is personal reputation, but also its interaction with the surrounding environment. To begin, we define reputation and discuss how it relates to similar constructs. Then, we show the necessity of viewing personal reputation in the context of an organization (i.e., as opposed to as an isolated construct). Next, we examine the current literature as it relates to the subject of personal reputation in organizations. Specifically, we build a foundation that is based on theoretical and empirical work that supports the current model being presented. Although this review consists mainly of research from the field of organizational behavior, due to the issue that the concept of personal reputation is still being developed, other fields will be referenced. Finally, a model will be presented that shows the relationship between personal reputation and the organization. In this representation, the individual basis for personal reputation is examined as well as how reputation is developed in an organization. We end this research with prospects for future studies.

\section{The Study of Personal Reputation Reputation}

Because the study of personal reputation is still in its infancy, there are still some issues regarding the differentiation of 
the construct from related phenomena. In the past, similar terms such as image, celebrity, and branding were used to describe reputation in the literature. This likely occurred because until recently reputation often went undefined in the literature (Zinko, Ferris, Blass, \& Laird, 2007). Because some of the texts that we are using to support the current model may use terminology that differs from "personal reputation;" it is appropriate to not only specifically define reputation, but also similar constructs in order to show how they vary from personal reputation.

Zinko et al. (2007) defined personal reputation as:

"a perceptual identity formed from the collective perceptions of others, which is reflective of the complex combination of salient personal characteristics and accomplishments, demonstrated behavior, and intended images presented over some period of time as observed directly and/or reported from secondary sources, which reduces ambiguity about expected future behavior" (p. 165).

This definition suggests that reputation differs from related constructs in various ways. Below, those constructs are examined in light of their relation to reputation.

\section{Status}

Ravlin and Thomas (2005, p. 968) characterized status as "differences in prestige and deference" that result in some sort of ranking. Likewise, Rindova, Pollock, and Hayward (2006) suggested that status is based more on networks and conformity to acceptable norms, and that one's place in the network often is related to the formal position an individual holds. That is to say, a portion (or all) of the value of the social power descriptor may be attached to the position held (e.g., a CEO or government official). This differs from reputation in that a portion of how individuals are viewed is tied to their positions. The individuals' actions are based on how well they follow the expected norms of the roles for which they are known. In this respect, status may be a part of reputation, but the construct of reputation remains too broad to be considered equivalent to status. Indeed, individuals may gain reputations that are completely unrelated to their formal positions. Furthermore, positive reputation is based upon positive deviations from norms (i.e., as opposed to status, which requires following those norms). For example, a junior academic who wins a relatively large number of research grants may develop a positive reputation even though her formal position, and hence status, does not change.

Interestingly, those who are the best at following the norms and expectations of a role may gain status; but in doing so, they actually deviate from the norms because only a few are able to achieve such levels of accomplishment in the role. It is this accomplishment that brings status (Rindova et al., 2006). Therefore, status may be considered to be a form of reputation.

\section{Image}

Like reputation, image is a socially constructed view (Zinko, Furner, Royle, \& Hall, 2010). Roberts (2005) suggested that image is based on our own assessment of ourselves, rather than an audience's perception of us; which implies that individuals' reputations may be completely different from their images. Essentially, our image is our own perception of our reputation. Individuals who are low in social astuteness may perceive their image as being something completely different 
from their reputation. However, recent work by Hochwarter, Ferris, Zinko, Arnell, and James (2007) has provided evidence that there is a significant relationship between how individuals view their own reputation and how others view it. Therefore, image and reputation, at times, may converge and be regarded as quite similar.

\section{Fame}

Fame relates to both celebrity and reputation. Zinko et al. (2007) suggested that fame acts like reputation except that it does not provide the predictability of reputation. Fame can be acquired through either a network (i.e., like reputation) or through the media (i.e., like celebrity). In both cases, fame is gained through a particular event. If the event has only occurred once, then although others will know the individual for the action, it lacks the repeatability to be used for prediction (Johnson, Erez, Kiker, \& Motowidlo, 2002). However, if an individual repeatedly performs this act over time, it can be considered reputation because others will expect the individual to perform in the same manner in the future (i.e., based on consistent past evidence). Therefore, a single event is able to bring fame, but not reputation (Zinko et al., 2007).

That being said, what may start off as fame may become reputation. If the event that made one famous is repeated often enough it will reduce ambiguity for the future, and others will be able to predict one's behavior under a certain set of circumstances.

\section{Celebrity}

Recent research has been conducted on both celebrity firms and celebrity CEOs (e.g., Hayward, Rindova, \& Pollock, 2004; Rindova et al., 2006). Rindova et al. defined celebrity as those entities that "attract a high level of public attention and generate positive emotional responses from stakeholder audiences" (p. 51). Celebrity is (often) caused by a large audience attributing the actions of an organization to an individual (Rindova et al., 2006). Although, both celebrity and reputation are based on others' perceptions of an individual (or group), the network that establishes celebrity is either purchased (e.g., public relations firms) or created by newscasters who, consistent with fundamental attribution theory (for a review, see Harvey \& Weary, 1984), attribute the causes of company changes to specific individuals. In an effort to gain television ratings, networks often create the celebrity reputation as opposed to individuals creating their own celebrity (Hayward et al., 2004).

This suggests that a CEO may gain celebrity purely though the public relations department of an organization working with the media. As the figureheads of organizations, individual CEOs may become celebrities, but they may not feel a need to adhere to the expectations that apply to what they are known for because they did not take an active role in the creation of their celebrity. On the other hand, reputation is actively built by the individual and, as such, the individual normally takes ownership of the reputation (Bromley, 2001). Ranft, Zinko, Ferris, and Buckley (2006) supported this notion by suggesting that individuals who have developed reputations may feel limited in their actions by those reputations. They proposed that if an action is not consistent with the reputation of the CEO, regardless of how such an action may benefit the company, the CEO may be hesitant to demonstrate it because they are concerned about diminishing their personal reputation. 
One of the major differences between the constructs of reputation and celebrity relates to the acceptance of the reputation by the individual in question. In the case of celebrity, the individuals may not care for what it is they are known.

Therefore, they may not always act in a way that is consistent with what people expect.

On the other hand, those who are attempting to build or maintain a reputation may be expected to act in a manner that is consistent with that reputation (Bromley, 2001). Since it cannot always be known whether individuals are actively seeking to reinforce their celebrity status, the prediction of behavior based on celebrity should be undertaken with caution.

\section{Pedigree}

Similar to status, in which a portion (or all) of the value of the social power descriptor may be attached to the position held, pedigree is wholly tied to an entity outside that of the individual but still directly affects the individual's reputation. Defined as the history or provenance of a person or thing, especially as conferring distinction (Oxford dictionaries online, 2014), pedigree is often seen to affect personal reputation when one has been associated with an elite organization (e.g., Harvard University, Navy SEALs, etc.). Because such an association deviates from the norms (i.e., not everyone has been a SEAL), part of what an individual is known for may emanate from this. Therefore, part of the reputation of the individual is based upon such associations and these associations often add credibility to the individual (Vedder \& Wachbroit, 2003).

\section{Legitimacy}

Rindova et al. (2006) suggested that legitimacy is primarily based on endorsements by a higher authority, which tend to occur when an individual fits well with the suggested values and norms. Rao (1994) suggested that legitimacy comes through institutional recognition and awards. Both legitimacy and reputation are created by others (i.e., legitimacy by higher authority and the institution, reputation by an audience). However, reputation can be more proactive. Individuals may create reputations for themselves (Ferris et al., 2003), whereas discrimination may prevent some individuals from attaining legitimacy regardless of their actions (Bojorquez \& Kleiner, 2005).

\section{Credibility}

Credibility is the "belief of an entity's intention at a particular time" (Herbig \& Milewicz, 1993, p. 19).

Credibility first must be established in order to interpret the "signaling" that occurs with respect to reputation (see Ferris et al., 2003). It is for this reason that current theory regarding reputation includes an assessment of the attributions of observed actions (see Zinko et al., 2007). If an audience feels that the actions of an individual are not authentic, then the reputation that occurs may be completely different from the one intended by the subject.

\section{Branding}

Branding is very similar to reputation development because both are an attempt to successfully influence those around us in order to achieve personal gain or rewards (Shepherd, 2005; Zinko et al., 2007). Personal branding is said to reflect the corporate branding process, and follows three stages.. First, those developing a personal brand identify their key attributes. Then, they construct a compelling 'personal brand statement' around this attribute set. 
Finally, they construct a strategy for making the brand visible to the outside world (Roffer, 2002). This is very similar to the promotion of reputation, but unlike branding, reputation may occur regardless of intent. Indeed, people often have unintentionally negative reputations.

\section{Impression Management}

Impression management refers to "the process by which individuals attempt to control the impressions others form of them" (Leary \& Kowalski, 1990, p. 34). Although several articles have linked impression management to reputation (e.g., Montagliani \& Giacalone, 1998; Stephens \& Greer, 1995), Bromley's (1993) work is perhaps the most comprehensive to date (Ferris et al., 2003). Bromley stated that individuals often do not know how others perceive them, but at times they sense how they are affecting others and try to change their behavior to obtain favorable impressions. Often viewed in association with the different "influence tactics" that individuals may use to manage their impressions, those attempting to manage others often have a specific goal, such as improving performance ratings (Dulebohn \& Ferris, 1999). In contrast, reputation is often viewed as a long-term investment with multiple outcomes desired (Barney, 1991; Rao, 1994). Furthermore, reputation includes more than just a manipulation of social power; it also includes tangible, verifiable past actions. Additionally, unlike impression management, the targets of reputation are often those who are not in direct contact with the individual (Zinko et al., 2007; Zinko, Gentry et al., 2012).

\section{Defining the Scope of the Study of Personal Reputation}

In summary, although personal reputation is closely related to several different constructs, it remains unique. We should also clarify that, because this review builds on existing theory, we restrict our view of personal reputation to that of positive reputation. Although negative reputation may indeed prove to be a significant construct, very few have attempted to research the negative side of this construct on the individual level (e.g., Harvey, Buckley, Heames, Zinko, Brouer, Ferris, 2007). Given that the purpose of this piece is to build upon existing theory in an effort to advance our knowledge of personal reputation, an attempt to include negative reputation in a meaningful way would be an excessive expansion of the scope of this study. Indeed, to even attempt to develop a meaningful definition as to what is negative reputation one must consider not only how others view the individual, but also the rewards granted for negative reputation. For example, if an organization is one that has a Machiavellian, cutthroat environment, then an individual who acts in an immoral manner may indeed be looked upon negatively by some peers, but positively by others. Would this individual be considered to have a positive reputation for being successful, or a negative one for being immoral? Would this individual hold both reputations at once or different reputations in different contexts? Due to the level of knowledge that still needs to be developed about an individual's reputation, to attempt to address both negative as well as positive reputations is beyond the scope of this examination.

\section{The Context of Personal Reputation}

Academics are frequently accused of examining single, isolated aspects of society and failing to put the constructs that they 
explore into context. In the case of organizational behaviorists, all too frequently we isolate a concept and make evaluations about it without considering the other facets of the organization in which we view that variable. Indeed, we often find the phrase, "these findings have limited generalization" in the discussion sections of manuscripts, suggesting that the context in which the construct is viewed is either nonexistent or limited. In viewing this problem of context in organizational behavior (OB), Porter (1996, p. 264) states that:

"probably the most significant failure of micro-OB, in my view, is that we have tended to ignore the "O" in our studies of micro phenomena. We clearly have emphasized the " $\mathrm{B}$ ", especially in recent years, but we have by and large been remiss in considering organizations as critical contexts affecting the behavior occurring within them."

In the years since Porter's critique, very little has changed as the same call for examining constructs in the context of which they exist persists (e.g., Johns, 2006).

Therefore, we must look at reputations in the context of the organization in which they exist.

Concepts such as basking in reflected glory, coat-tailing, and CEO celebrity have shown that an individual's reputation can affect more than just that individual; it can also affect the organization as a whole. For example, according to Byrne (1999), although "Chainsaw" Al Dunlap ended up destroying Sunbeam, the positive effect that he had on the stock price upon being hired was astounding. After triumphs at American Can, Lily Tulip, Crown Zellerbach, and Scott Paper, Al Dunlap's reputation had preceded him.
Even though he had yet to announce a single change, the company's stock rose $60 \%$ the day following the statement that Sunbeam had hired him. The change regarding the company's "worth" was based solely on value generated by the reputation of the new CEO.

Although research suggests that single individuals normally do not affect organizations in such major ways as to warrant such a response by the public (Meindl, Ehrlich, \& Dukerich, 1985), the perception of the organization by an audience may still change. Furthermore, an individual with a powerful reputation who belongs to or joins a group may not just affect the external view of an organization. Indeed, when an individual with a powerful reputation joins a new department of an organization as its head, that department may gain additional resources (Ferris, Perrewe, Ranft, Zinko, Stoner, Brouer, \& Laird, 2008).

When examining the benefits for the individual of building a personal reputation, a developing stream of literature exists. Tsui (1984) can, perhaps, be credited with first introducing personal reputation to the field of organizational behavior. Applying existing theory from the field of marketing, Tsui suggested that reputation fulfills marketing signals, whereby individuals communicate their intentions to an audience. She also showed that individuals can have multiple reputations, and that these reputations developed over time.

When viewing reputation in the context of organizations, one could surmise that an individual may be motivated to develop a reputation different than those they may have in other contexts. Indeed, Ferris et al. (2003) and Zinko et al. (2007) have suggested that individuals may use such abilities as political skill to not only 
assess what reputation may be appropriate for each organization an individual belongs to, but also how that individual may go about developing that reputation (i.e., this assertion regarding political skill was later supported empirically by Zinko, Ferris et al., 2012). The Ferris et al. study went on to show that reputations that are socially constructed are highly subjective in nature. In doing so, the importance of viewing reputation in the context of the organization to which it is a part of becomes apparent.

Similarly, Hayward et al. (2004) studied the closely related construct of celebrity. They found that like reputation, celebrity needs a vehicle (i.e., audience) to drive it. For celebrity, the "vehicle" is usually the media. In the case of personal reputation, the organization (i.e., via gossip) is how reputation is spread (Zinko et al., 2007). Foste and Botero (2012) examined the growth of reputation by considering both the method of communication of personal reputation as well as the "message" that was being spread. Their findings suggest that when individuals enter organizations, reputations are often used to "fill in the blanks" about new employees.

Current research shows additional aspects of an individual's reputation as it relates to others in the organization. Foste and Botero (2012) examined the effects that the reputations of new employees have on their supervisors. As reputations are often seen as a way of "signaling" ones intent to others (Ferris et al., 2003), Foste and Botero explored the outcomes of not only what the reputational message is expressing, but also how that message is delivered. They found that those who make requests that benefit the organization from their supervisors often enjoy a better reputation. Likewise, they found that those who make those requests in a nonaggressive style also hold a better reputation.

Building upon these outcomes, one can apply Pfeffer's (1992) links to personal reputation and power; in which he stated that individuals who have reputations for being powerful often gain even more power as their reputations spread. Pfeffer (1992) reasoned that a person reputed to be powerful will meet less resistance when trying to accomplish tasks; and because these results are observable, audiences will see the ease with which this individual is able to accomplish assignments and attribute more power to him or her. Therefore, it can be surmised that one can build power and reputation by requesting and receiving resources that may be of benefit to the organization. What is yet to be known is how external audiences will view an individual who builds their reputation via this method.

Laird, Zboja and Ferris (2012) also explored the effects that one's relationship with their supervisor has on personal reputation. In this, they did not explore requests for resources, but rather leader member exchange (LMX) and organizational citizenship behaviors (OCBs) as they related to the relationship between political skill and personal reputation. Their findings suggest that both LMX and also OCBs partially mediate the relationship between political skill and personal reputation. As Zinko et al. (2007) showed political skill to be an antecedent to personal reputation, the Laird at al. findings support the Ferris et al. (2003) notion that both actions (i.e., OCBs) as well as relationships (i.e., LMX) play a role in the development of personal reputation.

\section{External Views of Personal Reputation}


There has been limited exploration of personal reputation beyond the boundaries of the organization, thisexploration has normally been limited to CEOs. Nevertheless, this area of study warrants examination as it furthers our understanding of the relationship between what Kydd, Ogilvie, and Slade (1990) called our "internal reputation" (i.e., reputation being known within an organization") and our "external reputation" (i.e., our reputation outside of the organization). In exploring "external reputation", perhaps the best known examination is that of Meindl et al.'s (1985) The Romance of Leadership. This study explored how prominent leaders of companies are viewed as affecting both positive as well as negative outcomes of the organizations they run, regardless of the actual causes of the successes or failures of the companies. Meindl et al. surmised that audiences looking for causality may focus on the head of the organization, as opposed to fully analyzing the actual causal determinants of events and occurrences. This is consistent with Pfeffer (1977), who suggested that there is a propensity to credit high levels of control and influence to leaders; and that this tendency arises from private needs to find causes among human actors.

Earlier, Al Dunlap was used as an example of how the hiring of an individual as CEO may affect stock prices. The rise in Sunbeam's stock price would be based on how Dunlap may be viewed externally (Byrne, 1999). However, one may surmise that when an individual who has a reputation for cutting personnel is brought into an organization, his or her reputation would not be viewed positively by all audiences. Indeed, as reputations are based upon the norms and values of the group evaluating the individual, one would expect the reputation that such a manager would have with employees would differ greatly from that held by stockholders (Zinko et al., 2007). This would occur because different groups may interpret the exact same actions of an individual based upon different values, norms and biases. Indeed, a manager may have a reputation among his or her employees of being a tyrant, but be seen by the outside world as a brilliant leader (e.g., Steve Jobs) (Simon \& Young, 2005).

Additionally, the norms and values of an organization may shift over time. Therefore the concept that what causes a reputation to be built in one organization, but not another, can also be applied to time. What causes a positive reputation to be built in one period of time may not cause an equally positive reputation during another time period in an organization (Zinko, Ferris et al., 2012). For example, if managers in an organization relax their policy about casual attire in a workplace and an individual still dresses more formally (i.e., while those around this individual become more relaxed), the formal dress will cause the individual to now "stand out" even though the behavior has not altered, but rather the norms of the organization have changed. This individual would develop a reputation for dressing differently (i.e., more formally) than his or her peers.

\section{Social Media}

One of the most prominent ways that reputation can be transferred is via technology (e.g., email, Facebook, etc.). Social media is a relatively new phenomenon in the area of reputation. Social networking sites such as Facebook and LinkedIn enable people to connect and share information about themselves and their organizations with a large number of others online (Harris \& Rae, 2009). These 
new technologies have the potential to empower individuals and have some effect over their personal reputation. For example, they allow individuals to strategically manipulate their personal reputation by regulating the type of information that they display to others (i.e., signaling). Social media can also help to satisfy the need to belong because it allows individuals to embed themselves within a community of personally-relevant others (Yan, 2011). However, other aspects of social media pose potential threats to personal reputation because they are less controllable. For example, personal reputation can depend to some extent on the quality and quantity of connections that one has with others as well as personal endorsements from these others. Hence, personal reputation may be stunted if one has relatively few connections, the wrong type of connections, and/or limited endorsements.

\section{A Model of Personal Reputation in Organizations}

Although we have shown that there have been constructs that are related to personal reputation that look at how an individual is viewed beyond the organization (e.g., CEO celebrity), most current studies of leader reputation examine that reputation as viewed by those inside the organization (e.g., Blass \& Ferris, 2007; Mehra, Dixon, Brass, \& Robertson, 2006; Zinko, Gentry, et al., 2012) or by some outside the organization, but still stakeholders (e.g., customers, stock holders, etc.; e.g., Hall, Blass, Ferris, \& Massengale, 2004). This section builds upon these works, offering a model that combines existing theory in a synergistic manner in order to show not only the progression of the development of personal reputation in organizations, but also how those reputations may aid the organization.

Figure 1 proposes a model that adds to the existing literature on personal reputations by suggesting a clear understanding as to how individual and organizational bases for personal reputation interact and mesh with one another. This is accomplished by presenting the theory in three segments. The first section examines the "internal drivers" that propel an individual to develop and maintain a personal reputation. In this development, individuals foster images of themselves that they wish to strategically present to an audience. This image is driven by a need for self-esteem, a sense of belonging and a desire for rewards.

The next section of the model presents the organizational environment. This section details the role that the organization plays in the development of the reputation. It offers the "context" for the reputation in that it provides the norms against which the reputation is judged. That is to say, when the individual deviates positively from the norms in an attempt to develop a positive reputation, others consider that individual within the context of the values of the organization. The organization also provides a mechanism to develop the reputation of the individual via gossip (Zinko et al., 2007).

The final section of the model dictates the positive outcomes for both the individual as well as the organization. The majority of examinations of reputation explore the potential benefits of holding a positive reputation (e.g., Laird et al., 2008). In recognition of the relevance of such research, we focus on the existing empirical as well as theoretical findings regarding outcomes. We present both positive outcomes for the individual (e.g., power and 
career success) and the organization (e.g., the ability to predict the actions of the individual and basking). In doing so we show how one outcome (i.e., signaling) may be of benefit to both the organization as well as the individual.

Insert Figure 1 about here

\section{The Individual Drivers for a Personal Reputation}

Organizational scientists have acknowledged the motivations to build reputation and have couched them in more social terms, suggesting that these drives manifest themselves as the need for selfesteem, need for rewards, and a desire to signal who we are to others. The following section explores these drives as well as their positive outcomes (e.g., power and career advancement). The outcomes for the individual are presented along with the drives because one of the primary drives is a desire for rewards. To present them later in the document (i.e., alongside the benefits for the organization) would detract from the clarity of the text.

The need for self-esteem. In 1959, Cohen proposed that individuals are motivated not only to become their ideal selves, but also to convince others around them of this image. This psychological desire for a positive personal reputation exists in order to fill a basic need for both self-fulfillment and self-esteem (Baumeister, 1982; Leary \& Baumeister, 2000).

Essentially, human beings are social beings who have a natural drive to have others see them as they see themselves (De Cremer \& Tyler, 2005).

Building upon this notion, Tyler (2001) developed the concept of the reputational social self which posits that people are concerned about their personal reputation, as viewed by their peer group (Tyler \& Smith, 1997). Individuals usually form or join a social group. This group is typically the most pertinent source of the individual's personal reputation (Zinko et al., 2007). As such, these close knit social groups normally form the primary basis for an individual's self-respect and self-esteem (Baumeister, 1998). This view of personal reputation is supported by a number of different theories within social psychology. For example, in 1954, Festinger suggested that individuals have an inherent desire to accurately evaluate their own opinions and abilities. When objective measures are not available (as is often the case in social settings), individuals tend to measure themselves against others in their social setting. This allows individuals to assess their own reputations through evaluations of their behaviors; behaviors that are reflected back to them by members of the group (Emler \& Hopkins, 1990).

Identity theory supports a similar view of personal reputation in that it posits that the self is composed of several identities that reflect the different social positions that individuals hold within their various groups. These identities reflect individuals' views and beliefs of themselves (Stryker, 1980). Moreover, validations of these preconceived self-identities are reinforced when the social situations match the identities. Cast and Burke (2002) suggested that these validations imbue individuals with feelings of competency and worth (i.e., the two dimensions of self-esteem). Therefore, it can be argued that a need for self-esteem will motivate individuals to create a positive reputation.

Proposition 1: Individuals will be driven to
create a positive personal
reputation based upon a need
for self-esteem.


The need to belong. In addition to self-esteem, social psychologists have recognized the need to belong as a significant driver of a positive personal reputation (Baumeister \& Leary, 1995). Although the need to belong is related to the need for self-esteem, it remains a distinct construct (Zinko et al., 2007). The need to belong to a social group drives individuals to not only establish a personal reputation that enhances interpersonal bonds within groups, but also to develop apositive position, within the group (De Cremer \& Tyler, 2005).

Proposition 2: Individuals will be driven to create a positive personal reputation based upon a need to belong.

Signaling. The need to belong and to have others see us as we see ourselves may often result in an individual attempting to "signal" his or her intentions (Ferris et al., 2003). Zinko et al. (2007) suggested that individuals will likely focus on one or two traits for which they desire to be known, and this focus is normally on something in which they tend to excel. Standing out in such a way may send a message to those beyond their immediate surroundings that they desire to be identified by their performance in that area (Carroll, Green, Houghton, \& Wood, 2003). This phenomenon is reflective of established marketing theory (e.g., Erdem \& Swait, 1998), which dictates that reputation can be a form of "signaling" (Spence, 1974). It is also in accord with economic theory, which suggests that individuals influence reputations as a communication of specific characteristics to others (Diamond, 1989). Proposition 3: The development and maintenance of a personal reputation will result in individuals "signaling" their intention to others.

\section{The desire and attainment of}

rewards. Recent research regarding personal reputation has suggested that individuals with powerful reputations in organizations are granted benefits for holding those reputations. These rewards are often synergistically related. For example, autonomy, power, and career success can work together to increase one another as well as reputation (Zinko, Ferris et al., 2012). Although such rewards are not an exhaustive list of the benefits of reputation, they do represent a well-defined set of theoretically-sound results of reputation that have been shown to exist across fields.

As set forth above, autonomy is one of the recognized results of reputation. Theory suggests that autonomy within an organization will increase if an individual has a powerful personal reputation because organizations feel less of a need to monitor that person's activities as closely as they might otherwise (Zinko et al., 2007). Such a decrease in monitoring is feasible for organizations because individuals value their reputations and will not readily destroy them by acting in a manner that is contradictory to those established reputations (Emler, 1984). As a result, organizations are able to utilize reputations to predict an individual's behavior. Agency theory (for a review, see Eisenhardt, 1989 ) as well as the developing stream of celebrity literature also support a direct connection between autonomy and personal reputation by suggesting that those responsible for hiring may seek out individuals who have established reputations because of a belief that those individuals who have predictable behavior require less supervision (Hayward et al., 2004). This was the theoretical basis for Zinko, Ferris et 
al.'s (2012) study, which provided an empirical test of the link between reputation and autonomy and found a direct, significant, relationship.

Proposition 4a: Individuals will develop a reputation with the intent of increasing autonomy.

Proposition 4b: There is a positive relation between positive personal reputation and autonomy.

In addition to receiving increased autonomy, those individuals with strong positive personal reputations may also be rewarded with increased power. Such phenomena occur because of the desire of others to be identified or associated with individuals who have positive personal reputations. In the field of social psychology, this phenomenon is referred to as "basking in reflected glory" (see Cialdini, Borden, Thorne, Walker, Freeman, \& Sloan, 1976 for an overview). Likewise, there is also a significant body of literature in the field of child psychology discussing the power that personal reputation brings to individuals. This literature predominately focuses on the study of inner-city gangs. Gang-members desire reputations for being tougher than those around them. Gaining this reputation not only rewards the gang members' efforts to rise to leadership but also helps them to maintain control of their leadership positions (Emler, 1984). Such a result is also in accord with Pfeffer's (1992) suggestion that a personal reputation for being a powerful individual brings even more power.

Proposition 5a: Individuals will develop a reputation with the intent of increasing power.

Proposition 5b: There is a positive relation between positive personal reputation and power.
Career success is yet another outcome of personal reputation. Ferris and Judge (1991) argued that workplace achievements are based more on social factors than they are on objective performance measures. This suggests that those with powerful reputations would be able to use their reputations in a way that would influence those around them. Furthermore, even when objective measures are utilized, personal reputation has been shown to be related to actual performance (e.g., Herbig \& Milewicz, 1993; Zinko, Ferris et al., 2012). These results are not surprising because reputation has been theorized to affect such career advancement measures as performance evaluations, promotions, employee mobility, and compensation (Ferris et al., 2003).

Proposition 6a: Individuals will develop a reputation with the intent of increasing career success.

Proposition 6b: There is a positive relation between personal reputation and career success.

In offering these outcomes for personal reputation, it must be noted that not all types of reputations will result in all proposed outcomes. Indeed, theory suggests that reputation may be based upon more than just the tasks that one performs as part of his or her job description. Reputation may be based on social aspects such as being "the life of the party" or the level of one's integrity (i.e., is this person trustworthy?; Zinko, Gentry, et al., 2012; Zinko et al., 2007). When considering social reputations, research has suggested that those who are highly politically skilled often develop social reputations in which they are fast-tracked, often beyond their technical abilities (i.e., receiving rewards of power, autonomy, and career success). On the other hand, others might develop 
positive social reputations for being likeable, but audiences may not see likeability as a reason to grant such rewards. Likewise, some individuals who possess great technical skill may gain a certain level autonomy, but may not necessarily advance in their chosen career (Ferris et al., 2003). Although reputation has been shown to be typically advantageous, it does not automatically equate to success.

\section{The Organization as a Context for Establishing Personal Reputations}

Reputations are the result of information based upon observed behaviors that are shared and transmitted among members of a group who hold an agreed upon perception of an individual (Zinko et al., 2007). As such, reputations exist within the social norms and values of an organization. Therefore, in order to understand how reputations occur, they must be examined in the context of organizations. What might be unusual in one organization may be common place in another. These behaviors must be uncommon enough so that others will find them interesting enough to report the behaviors to others (Haviland, 1977). In order to define this uniqueness, the organizational setting must be supplied because such context provides the norms and values that dictate what is "interesting" enough to be discussed (Zinko et al., 2007).

This organizational setting may play a key factor in dictating which organizations an individual might seek to join. In the case of high performers, for instance, they may prefer to remain a "big fish in a small pond," as opposed to seeking entry into an organization where their high level of performance is considered common place and, therefore, not special or extraordinary (i.e., and as such, the individual's actions won't warrant discussion by others, as what is being done is no longer out of the norm when compared to others' behaviors). This is but one example of how the norms and values of the organization dictate the actions or behaviors of an individual. Those observing such actions must do so within the context of the organization in order to place an accurate positive or negative value upon the actions.

To illustrate, when examining a behavior that appears to be a deviation from the norm, the observers must view the action utilizing the anticipations and assumptions that are a part of that organization. These anticipations and assumptions are based on past information about the individual in question (Weick, 1979) as well as expected norms derived from roles consistent with the context being observed (Tsui, 1984). When individuals deviate from expected norms, others around them attempt to make sense of their actions within the context of the organizational norms (Biddle \& Thomas, 1966). Any deviation that strays too far from these expected norms results in what Weick (1979, p. 4) refers to as a "surprise".

When there is a surprise, the observers feel a need to make sense of the situation (Weick, 1979); those individuals who have observed the unusual behavior seek to understand and attribute the cause of the event (Heider, 1958). The framework for this consideration is that of the organizational norms and values, applied to the prescribed role of the individual (Emler, 1994). Over a period of time, the observers' continued assessments of the unusual actions of an individual result in the creation of a reputation for the individual who engaged in the unusual actions (Biddle \& Thomas, 1966). Once this reputation is established, audiences will then imbue that individual with the appropriate rewards. 
Likewise, Turner, Hogg, Oakes, Reicher, and Wetherell (1987) stated that social identities influence one's image because audiences categorize, stereotype, and interpret the behaviors of others depending upon their expectations of the group they identify the other with. This relates again to norms. Varied groups and organizations will have different norms and values, but some of those constructs are derived from the larger society in which the group is nested. In demonstrating the influence of norms, Zinko et al. (2012) gave the example of an individual that may become "known" for being an excellent singer in his or her church; however, individuals at the subject's workplace may not care about singing, and as such will not talk about it (Emler, 1994). Consequently, no workplace reputation based on singing will be formed. Therefore, in order to gauge reputation, the measure used must reflect the environment in question. That being said, if the individual wins a national singing competition (e.g., America's Got Talent), then this individual will also be known for that accomplishment in both the choir as well as his or her workplace, because becoming a star on TV deviates positively from societal norms, the norms to which both the work group as well as the choir adhere. Similarly, if society as a whole attaches a characteristic to a group of people via stereotyping (e.g., Asians are good at math), then one could argue that those wishing to build a reputation may capitalize on what others may already believe (i.e., based on preconceived notions of the group to which that individual belongs).

Therefore, if one is being stereotyped, characteristics are already being assigned to an individual. If these characteristics are not the norm, then a reputation may be built upon this belief.

\section{The strategic manipulation of} personal reputation. Although reputations are decided by an audience, individuals do have some influence regarding how others view them. This influence is garnered by regulating the behaviors that others observe. By engaging in such reputation building, an individual's behavior may signal to others that which he/she wishes to communicate. To explain this phenomenon, Zinko et al. (2007) applied Carver and Scheier's (1981) theory of self-regulatory process. The first step in this process is for the individual to compare the current situation to that of a standard or norm. If the current situation cannot be reconciled with the standard, then most individuals will attempt to alter their behavior to align the situation with that standard or norm.

Once the regulating behavior is performed, the situation will be reevaluated, and if it still cannot be reconciled with the norm, then the behaviors will continue to be motivated and altered to reduce this discrepancy until the situation matches the norm (Baumeister, Heatherton, \& Tice, 1994). Those who are attempting to build reputations, however, do not follow this pattern. Indeed, Zinko et al. (2007) suggest that instead of attempting to normalize the situation, those who are attempting to build a reputation will use this process to define the standard, then deliberately deviate from this norm in an effort to be noticed (i.e., signaling their intentions). Such behavior is similar to the adaptive self-regulation approach to managerial effectiveness proposed by Tsui and Ashford (1994). Proposition 7: Positive reputations are established by deviating positively from norms.

Organizational dissemination of personal reputations. Although an individual is able to control his or her 
actions and may thus have some influence over his/her reputation, reputation is nevertheless ultimately determined by an audience. One of the primary mechanisms by which an audience determines a reputation is by the observation of deviations of behavior beyond what the organizational norms would normally prescribe. The audience transfers these observations to others through the dissemination of gossip (Zinko et al., 2007). Unlike information that is received directly from an individual attempting to create a reputation, information received through gossip is more readily believed and accepted by an audience. This belief is fostered by suspicions that information received directly from the individual is self-serving and, therefore, untrustworthy (Haviland, 1977).

Although gossip may be viewed as negative in organizations (e.g., Baumeister, Zhang, \& Vohs, 2004), in the context of personal reputation, it is a necessary component (Zinko, et al., 2007). Defined as "idle talk" or "chit chat" about daily life, gossip contains an evaluative component regarding its subject (Haviland, 1977). It is this evaluative aspect that is crucial for developing and maintaining a reputation. Gossip provides a mechanism by which the conclusions of this evaluation can be disseminated. It is this dissemination that spreads the reputation of the individual who engaged in the unusual behavior throughout the organization (Emler, 1994; Zinko et al., 2007). The group assessment also serves as a mechanism by which the group increases social bonds and solidarity by holding an agreed upon interpretation of witnessed and relayed events (Noon \& Delbridge, 1993). Proposition 8: Reputation is disseminated through gossip.

Positive Outcomes for the Organization
There are many benefits that individuals derive through the development of positive personal reputations. As explained earlier, reputations are used to obtain rewards such as autonomy, power, and career success (e.g., Zinko, Ferris et al., 2012). They are used to satisfy individual needs for positive self-esteem and to secure a sense of belonging. They are also utilized as tools whereby key information about an individual is signaled to others (Ferris et al., 2003). It is not solely individuals, however, that may benefit from the use of personal reputations. Organizations also have the potential to affect and benefit from aspects of the personal reputations of members. In the following sections, we discuss how organizations utilize personal reputations to predict an individual's behavior, market individuals, build their own corporate reputations, and signal information to consumers and competitors.

\section{Predicting individuals' behaviors.}

One manner in which an organization may obtain a benefit from the personal reputation of an individual is through recognition that a personal reputation can be used to predict an individual's behavior. Because there is often uncertainty as to the level of trust that should be granted to an individual, organizations look toward reputations in order decrease ambiguity about the individual. For example, if an individual has a reputation for successfully leading organizations into innovations, it can be assumed that this behavior will continue once they become a part of the new organization. This past behavior and the developed reputation is used by organizations to render predictions about future behavior and reduces the risk of employing ineffective individuals (Zinko et al., 2007). 
The advantages that organizations derive from employing individuals with established reputations can also be viewed in terms of organizational efficiency. Using agency theory, those in power can use reputation to assess the individual in questing via a cost/benefit analysis (i.e., the cost of monitoring an individual's actions must be measured against the potential benefit of allowing the individual entry into the organization; Eisenhardt, 1989). If the individual has a solid positive reputation, the management can expect certain behaviors reflective of that reputation. Organizational resources may not need to be allocated to monitoring and are instead available for assignment to other areas or to simply be held in reserve. Therefore, one could argue that positive personal reputation has a favorable impact upon the overall efficiency of the organization.

Proposition 9: Established reputations are characterized by a level of predictability.

Basking in the reflected glory of individuals. Organizations also have a vested interest in being associated with individuals who have a powerful and positive reputation. As noted earlier, individuals may bask in the reflected glory of other individuals' personal reputations. This desire to be around and associated with those who have a powerful reputation is not simply to gain rewards. Indeed, research suggests that there is a primal drive to be associated with such individuals. In an experiment with primates, Deaner, Khera, and Platt (2005) found that monkeys would rather view a photo of a higher status monkey than gain a physical reward (i.e., a serving of juice that the monkeys were shown to enjoy). Similarly, Helm (2011) found that employees' perceptions of corporate reputation positively predicted their pride in being affiliated with the corporation. Findings such as these suggest that there exists a willingness to make sacrifices in order to be around those who we perceive to be socially superior to us. It could be argued that this desire to be near those with power is one of the driving mechanisms behind basking.

When considering organizations, one can suggest that similar benefits can be gained from the personal reputations of its members. Organizational basking results in an audience reassessment of the organization to now include the reputation of the individual who is part of that group. The organization is then seen in a more favorable light by the audience. This can manifest itself in several positive manners such as through stock price increases or, if the basking is confined to a specific department within the organization, through the allocation of additional resources to that department (Ferris et al., 2008). For this reason, organizations may often be involved in "purchasing" an individual's personal reputation.

This phenomenon is perhaps most readily illustrated in the arena of professional sports. For example, when Michael Jordan left basketball and joined a minor league baseball team, the team was not only purchasing his skill as a baseball player (which was widely acknowledged to be far below his skill as a basketball player through which he attained his fame), but also his fame as a sports figure in general. The famous basketball player, Michael Jordan, became part of the product that was the minor league baseball team. This organizational basking resulted in increased ticket and product sales (Halberstam, 2012).

In sum, when an organization takes in an individual with a powerful reputation, that individual becomes part of how that 
organization is perceived (Wade, Porac, Pollock, \& Graffin, 2006). Thus, a positive perception of an individual may be transferred to the perception of the organization. The potential benefit that an organization may receive from such transference is limited only by the boundaries of the reputation of the individual. The more powerful the reputation of the individual, the more powerful the reputation of the organization may become. Moreover, this basking is not limited solely to the organization as a whole but may also be reflected within particular departments of the organization. Proposition 10: Established reputations may lead to an enhanced reputation for the organization via basking in reflective glory.

\section{Organizational signaling. We}

propose that signaling is yet another benefit of reputation building that is shared by both individuals and the organization as a whole. Like individuals, organizations may signal their intentions though actions. For example, the entry of an individual with a positive reputation into the organization sends a positive signal to the audience. In the marketing arena, positive signaling communicates a message to consumers and competitors that the organization is responding to market expectations. To illustrate, when Apple sales were slumping in 2005 , the company brought back Steve Jobs, and the market responded positively, due to the message that Apple was sending by rehiring Steve Jobs. Jobs was known as an innovator, a reputation that Apple was losing. By associating themselves with Jobs, Apple was able to signal their intent to return to innovation (Simon \& Young, 2005). Such signaling, over time will build an organization a positive reputation (Herbig \& Milewicz, 1993).

Proposition 11: Organizations may signal intent to external audiences via the reputations of their members.

\section{Conclusion}

An examination of personal reputation across fields reveals several common themes that are appropriate for unification. The model presented in this paper is an effort to begin that process. It proposes that there is a complex set of dynamics that underlie personal reputation in organizations. Contextually, organizations are shown to be essential frameworks within which individuals realize or attain their personal reputations. Within this framework, organizational gossip is used to disseminate information about individuals and create or enhance a member's personal reputation. For those individuals who enter into the organization already in possession of powerful personal reputations, the organization may attempt to leverage that reputation to improve its own standing with audiences. The organization is able to use the personal reputation of the new member to signal a specific positive message to its target audience. When considering the benefits for the individual as well as the organization signaling is an important factor.

Although this examination of reputation links together themes across fields, it is in no way exhaustive of the nuances and findings contained within specific areas of study. Rather, the findings presented in this study are offered as a framework for future research into personal reputation. Further study regarding the subject matter is necessary to better understand the construct. The following section discusses the limited scope of this 
review as well as offers guidance for future inspections.

\section{Limitations and Future Research}

In this review, only the positive aspects of reputation and its potential benefits for the individual and his/her organization have been discussed. The association between a negative personal reputation and that of the organizations has yet to be fully explored. An examination of this relationship could provide a significant contribution to the field because an individual's personal reputation may adversely impact both the individual and his/her organization.

Additionally, the possibility that a synergistic relationship may develop between powerful individuals and powerfully reputed organizations when the individual becomes a member of the organization also represents an area ripe for research. In such a situation, it may well be that both the individual as well as the organization reap rewards, or perhaps one reputation may overshadow the other. An example of this overshadowing may occur when an individual considered a superstar or a "big fish in a small pond" at one organization joins an organization of superstars. That individual may no longer reap the rewards that were available at his/her previous organization because those same qualities are not considered special or extraordinary at the new organization.

An exploration of the manner in which different dimensions of an individual's reputation affect his or her organization may also be worthy of examination. Although this review only addressed reputation as a general concept; in actuality, there may be several dimensions. For example, individuals may be known in an organization for their level of work (e.g., being an expert in a specific task), but also for social aspects (e.g., being the superstar of the company's softball league). It is also possible that an individual may have both negative and positive dimensions to his reputation. Determining which dimensions contribute to a positive organizational outcome could provide a significant advance in the field.

Although we address one's personal reputation on-line, as what is considered "on-line" is still being developed, so too must our examination of on-line reputation. Indeed, the migration from such networks as Myspace onto Facebook and LinkedIn, then to Twitter and Snapchat offers a continuous development of not only social platforms, but also tools for developing reputations. Furthermore, with the speed at which information is now shared, will the building of reputations also become faster? The implementation of technology in the development of reputation will also have to address the issue of how much an audience trusts the source of the information that is made available. Indeed, audience members hear about a deviation from the norms via others. Typically, this is a trusted colleague (Zinko et al., 2007). As technology becomes more a part of our lives, it will become more important to empower individuals to make valid appraisals about the trustworthiness of the sources of information that they are accessing.

An additional issue, one that plagues many constructs in the organizational sciences, is the parallel existence of similar concepts across the different fields. The first few pages of this article were spent clarifying the differences and similarity between constructs such as impression management, fame, branding, etc. As personal reputation is still relatively new in the management literature, much can be 
learned by examining similar constructs and findings from other fields. Indeed, the area of corporate reputation, while different in many ways, may hold the answer to several questions regarding personal reputation.

Likewise, the relationship between corporate reputation and personal reputation is worthy of examination. Although this article outlines a general relationship between the two, further scrutiny is warranted. 


\section{References}

Barney, J. (1991). Firm resources and sustained competitive advantage. Journal of Management, 17, 99-120.

Baumeister, R. F. (1982). A selfpresentational view of social phenomena. Psychological Bulletin, 91, 3-26.

Baumeister, R. F. (1998). The self. In D. T. Gilbert, S. T. Fiske, \& G. Lindzey (Eds.), Handbook of Social Psychology (4th ed., pp. 680-740). New York: McGraw-Hill.

Baumeister, R. F., \& Leary, M. R. (1995). The need to belong: Desire for interpersonal attachments as a fundamental human motivation. Psychological Bulletin, 117, 497529.

Baumeister, R. F., Heatherton, T. F., \& Tice, D. M. (1994). Losing control: How and why people fail at selfregulation. New York: Academic Press.

Baumeister, R. F., Zhang, L., \& Vohs, K. D. (2004). Gossip as cultural learning. Review of General Psychology, 8, 111-121.

Biddle, B., \& Thomas, E. (1966). Role theory: Concepts and research. New York: Wiley.

Blass, F. R., \& Ferris, G. R. (2007). Leader reputation: The role of mentoring, political skill, contextual learning, and adaptation. Human Resource Management, 46, 5-19.

Bojorquez, D., \& Kleiner, B. H. (2005). How to validate conclusions regarding discrimination based on EEOC criteria. Equal Opportunities International, 24, 59-67.

Byrne, J. A. (1999). Chainsaw: The notorious career of Al Dunlap in the era of profit-at-any-price. New York: HarperBusiness.

Bromley, D. (1993). Reputation, image, and impression management. United Kingdom: University of Liverpool.

Bromley, D. (2001). Relationships between personal and corporate reputation. European Journal of Marketing, 35, 316-334.

Carroll, A., Green, S., Houghton, S., \& Wood, R. (2003). Reputation enhancement and involvement in delinquency among high school students. International Journal of Disability, Development and Education, 50, 253-272.

Carver, C. S., \& Scheier, M. R. (1981). Attention and self-regulation: A control theory approach to human behavior. New York: SpringerVerlag.

Cast, A. D., \& Burke, P. J. (2002). A theory of self-esteem. Social Forces, 80, 1041-1068.

Cialdini, R. B., Borden, R. J., Thorne, A., Walker, M. R., Freeman, S., \& Sloan, L. R. (1976). Basking in reflected glory: Three (football) field studies. Journal of Personality and Social Psychology, 34, 366-375.

Cohen, A. R. (1959). Some implications of self-esteem for social influence. In C. I. Hovland \& I. L. Janis (Eds), Personality and persuasibility (pp. 102-120). Oxford, England: Yale University Press.

De Cremer, D., \& Tyler, T. R. (2005). Am I respected or not?: Inclusion and reputation as issues in group membership. Social Justice Research, 18, 121-153.

Deaner, R. O., Khera, A. V., \& Platt, M., (2005). Monkeys pay per view: Adaptive valuation of social images 
by Rhesus Macaques. Current Biology, 15, 543-548.

Diamond, D. W. (1989). Reputation in debt markets. The Journal of Political Economy, 97, 828-862.

Dulebohn, J. H., \& Ferris, G. R. (1999). The role of influence tactics in perceptions of performance evaluations' fairness. Academy of Management Journal, 42, 288-306.

Eisenhardt, K. M. (1989). Agency theory: An assessment and review. Academy of Management Review, 14, 57-74.

Emler, N. (1984). Differential involvement in delinquency: Toward an interpretation in terms of reputation management. Progress in Experimental Personality Research, 13, 173-239.

Emler, N., \& Hopkins, N. (1990). Reputation, social identity, and the self. In D. Abrams \& M. A. Hogg (Eds.), Social identity theory: Constructive and critical advances. New York: Springer-Verlag.

Erdem, T., \& Swait, J. (1998). Brand equity as a signaling phenomenon. Journal of Consumer Psychology, 7, 131157.

Ferris, G. R., \& Judge, T. A. (1991). Personnel/human resources management: A political influence perspective. Journal of Management, 17, 447-488.

Ferris, G. R., Blass, F. R., Douglas, C., Kolodinsky, R. W., \& Treadway, D. C. (2003). Personal reputation in organizations. In J. Greenberg (Ed.), Organizational behavior: The state of the science ( $2^{\text {nd }}$ ed., pp. 211-246). Mahwah, NJ: Lawrence Erlbaum.

Ferris, G. R., Perrewe, P. L., Ranft, A. L. , Zinko, R., Stoner, J. S. , Brouer, R. L., \& Laird, M. D. (2008). Human resources reputation and effectiveness. Human Resource Management Review, 17, 117-130.

Festinger, L. (1954). A theory of social comparison processes. Human Relations, 7, 117-140.

Foste, E. A., \& Botero, I. C. (2012). Personal reputation effects of upward communication on impressions about new employees. Management Communication Quarterly, 26, 4873.

Gray, E. R., \& Balmer, J. M. (1998). Managing corporate image and corporate reputation. Long Range Planning, 31, 695-702.

Halberstam, D. (2012). Playing for keeps: Michael Jordan and the world he made. New York: Open Road Media.

Hall, A. T., Blass, F. R., Ferris, G. R., \& Massengale, R. (2004). Leader reputation and accountability in organizations:

Implications for dysfunctional leader behavior. The Leadership Quarterly, 15, 515-536.

Hall, A. T., Zinko, R., Perryman, A. A., \& Ferris, G. R. (2009). Organizational citizenship behavior and reputation: Mediators in the relationships between accountability and job performance and satisfaction. Journal of Leadership and Organizational Studies, 15, 381392.

Harris, L., \& Rae, A. (2009). Social networks: The future of marketing for small business. Journal of Business Strategy, 30, 24-31.

Harvey, J. H., \& Weary, G. (1984). Current issues in attribution theory and research. Annual Review of Psychology, 35, 427-459.

Harvey, M. G., Buckley, M. R., Heames, J. T., Zinko, R., Brouer, R. L., Ferris, G. R., (2007). A bully as the archetypal 
destructive leader. Journal of Leadership and Organizational Studies, 14, 117-129.

Haviland, J. (1977). Gossip, reputation, and knowledge in Zinacantan. Chicago: University of Chicago Press.

Hayward, M. L. A., Rindova, V. P., \& Pollock, T. G. (2004). Believing one's own press: The causes and consequences of CEO celebrity. Strategic Management Journal, 25, 637-653.

Heider, F. (1958). The psychology of interpersonal relations. New York: Wiley.

Helm, S. (2011). Employees' awareness of their impact on corporate reputation. Journal of Business Research, 64, 657-663.

Herbig, P., \& Milewicz, J. (1993). The relationship of reputation and credibility to brand success. Journal of Consumer Marketing, 10, 18-24.

Hochwarter, W. A., Ferris, G. R., Zinko, R., Arnell, B., \& James, M. (2007). Reputation as a moderator of the political behavior--work outcomes relationships: A two-study investigation with convergent results. Journal of Applied Psychology, 92, 567-576.

Johnson, D. E., Erez, A., Kiker, D. S., \& Motowidlo, S. J. (2002). Liking and attributions of motives as mediators of the relationship between individuals' reputations, helpful behaviors, and raters' reward decisions. Journal of Applied Psychology, 87, 808-815.

Kydd, C. T., Ogilvie, J. R., \& Slade, L. A. (1990). "I don't care what they say, as long as they spell my name right": Publicity, reputation and turnover.
Group and Organizational Studies, 15, 53-74.

Laird, M. D., Perryman, A. A., Hochwarter, W. A., Ferris, G. R., \& Zinko, R. (2008). The moderating effects of personal reputation on accountability--strain relationships. Journal of Occupational Health Psychology, 14, 70-83.

Laird, M. D., Zboja, J. J., \& Ferris, G. R. (2012). Partial mediation of the political skill-reputation relationship. Career Development International, 17, 557-582.

Laird, M. D., Zboja, J. J., Martinez, A. D., \& Ferris, G. R. (2013). Performance and political skill in personal reputation assessments. Journal of Managerial Psychology, 28, 661676.

Leary, M. R., \& Baumeister, R. F. (2000). The nature and function of selfesteem: Sociometer theory. Advances in Experimental Social Psychology, $32,1-62$.

Leary, M. R., \& Kowalski, R. M. (1990). Impression management: A literature review and two-component model. Psychological Bulletin, 107, 34-47.

Mehra, A., Dixon, A. L., Brass, D. J., \& Robertson, B. (2006). The social network ties of group leaders: Implications for group performance and leader reputation. Organization Science, 17, 64-79.

Meindl, J. R., Ehrlich, S. B., \& Dukerich, J. M. (1985). The romance of leadership. Administrative Science Quarterly, 30, 78-102.

Montagliani, A., \& Giacalone, R. A. (1998). Impression management and crosscultural adaptation. Journal of Social Psychology, 138, 598-608. 
Noon, M. \& Delbridge, R. (1993). News from behind my hand: Gossip in organizations. Organization Studies, 14, 23-36.

Oxford dictionaries online. (2014). Retrieved from http://www.oxforddictionaries.com/

Pfeffer, J. (1977). The ambiguity of leadership. Academy of Management Review, 2, 104-112.

Pfeffer, J. (1992). Managing with power: Politics and influence in organizations. Boston: Harvard Business School Press.

Porter, L.W. (1996). Forty years of organization studies: Reflections from a micro perspective. Administrative Science Quarterly, 41, 262-269.

Ranft, A. L., Zinko, R., Ferris, G.R., \& Buckley, M.R. (2006). Marketing the image of management: The costs and benefits of CEO reputation. Organizational Dynamics, 35, 279290.

Rao, H. (1994). The social construction of reputation: Certification contests, legitimation, and the survival of organizations in the American automobile industry: 1895-1912. Strategic Management Journal, 15, 29-44.

Ravlin, E. C., \& Thomas, D. C. (2005). Status and stratification processes in organizational life. Journal of Management, 31, 966-987.

Rindova, V. P., Pollock, T. G., \& Hayward, M. L. A. (2006). Celebrity firms: The social construction of market popularity. Academy of Management Review, 31, 50-71.

Roberts, L. M. (2005). Changing faces: Professional image construction in diverse organizational settings.
Academy of Management Review, 30, 685-711.

Roberts, P. W., \& Dowling, G. R. (2002). Corporate reputation and sustained superior financial performance. Strategic Management Journal, 23, 1077-1093.

Roffer, R. F. (2002). Make a name for yourself: Eight steps every woman needs to create a personal brand strategy for success. New York, NY: Broadway.

Shepherd, I. D. (2005). From cattle and coke to Charlie: Meeting the challenge of self-marketing and personal branding. Journal of Marketing Management, 21, 589-606.

Simon, W. L., \& Young, J. S. (2005). iCon: Steve Jobs, The greatest second act in the history of business. Hoboken, NJ: Wiley.

Spence, A. M. (1974). Marketing signaling: Informational transfer in hiring and related screening processes. Cambridge, MA: Harvard University Press.

Stephens, G. K., \& Greer, C. R. (1995). Doing business in Mexico: Understanding cultural differences. Organizational Dynamics, 24, 39-56.

Stryker, S. (1980). Symbolic interactionism: A social structural version. Menlo Park, CA: Benjamin/Cummings.

Tsui, A. S. (1984). A role set analysis of managerial reputation. Organizational Behavior and Human Performance, 34, 64-96.

Tsui, A. S., \& Ashford, S. J. (1994). Adaptive self-regulation: A process view of managerial effectiveness. Journal of Management, 20, 93-121.

Turner, J. C., Hogg, M. A., Oakes, P. J., Reicher, S. D., \& Wetherell, M. S. (1987). Rediscovering the social 
group: A self-categorization theory. Oxford, UK: Blackwell.

Tyler, T. R. (2001). Cooperation in organizations: A social identity perspective. In M. A. Hogg, and D. J. Terry (Eds.), Social identity processes in organizational contexts (pp. 149-166). Philadelphia, PA: Psychology Press.

Tyler, T. R., \& Smith, H.J. (1997). Social justice and social movements. In D. Gilbert, S. T. Fiske, \& G. Lindzey, (Eds.), Handbook of social psychology. New York: McGraw Hill.

Vedder, A., \& Wachbroit, R. (2003). Reliability of information on the Internet: Some distinctions. Ethics and Information Technology, 5, 211215.

Wade, J. B., Porac, J. F., Pollock, T. G., \& Graffin, S. D. (2006). The burden of celebrity: The impact of CEO certification contests on CEO pay and performance. Academy of Management Journal, 49, 643-660.

Weick, K. (1979). The social psychology of organizing (2nd ed.). Reading, MA: Addison-Wesley.

Yan, J. (2011). Social media in branding: Fulfilling a need. Journal of Brand Management, 18, 688-696.

Zinko, R. A. (2013). A continued examination of the inverse relationship between political skill and strain reactions: exploring reputation as a mediating factor. Journal of Applied Social Psychology, 43, 1750-1759.

Zinko, R., Ferris, G. R., Blass, F. R., \& Laird, M. D. (2007). Toward a theory of reputation in organizations. In J.J. Martocchio (Ed.), Research in personnel and human resources management. Oxford, UK: JAI Press/Elsevier Science.

Zinko, R., Ferris, G. R., Humphrey, S. E., Meyer, C. J., \& Amie, F. (2012).

Personal reputation in organizations: Two-study constructive replication and extension of antecedents and consequences. Journal of Occupational and Organizational Psychology, 85, 156-180.

Zinko, R., Furner, C. P., Royle, T., \& Hall, A. (2010). Self-perceptions of our personal reputations: The mediating role of image in the development of organizational citizenship behaviors. Journal of International Management Studies, 5, 1-9.

Zinko, R., Gentry, W. A., Hall, A., \& Grant, G. L. (2012). Reputational change among managers. Journal of Managerial Issues, 24, 9-26. 


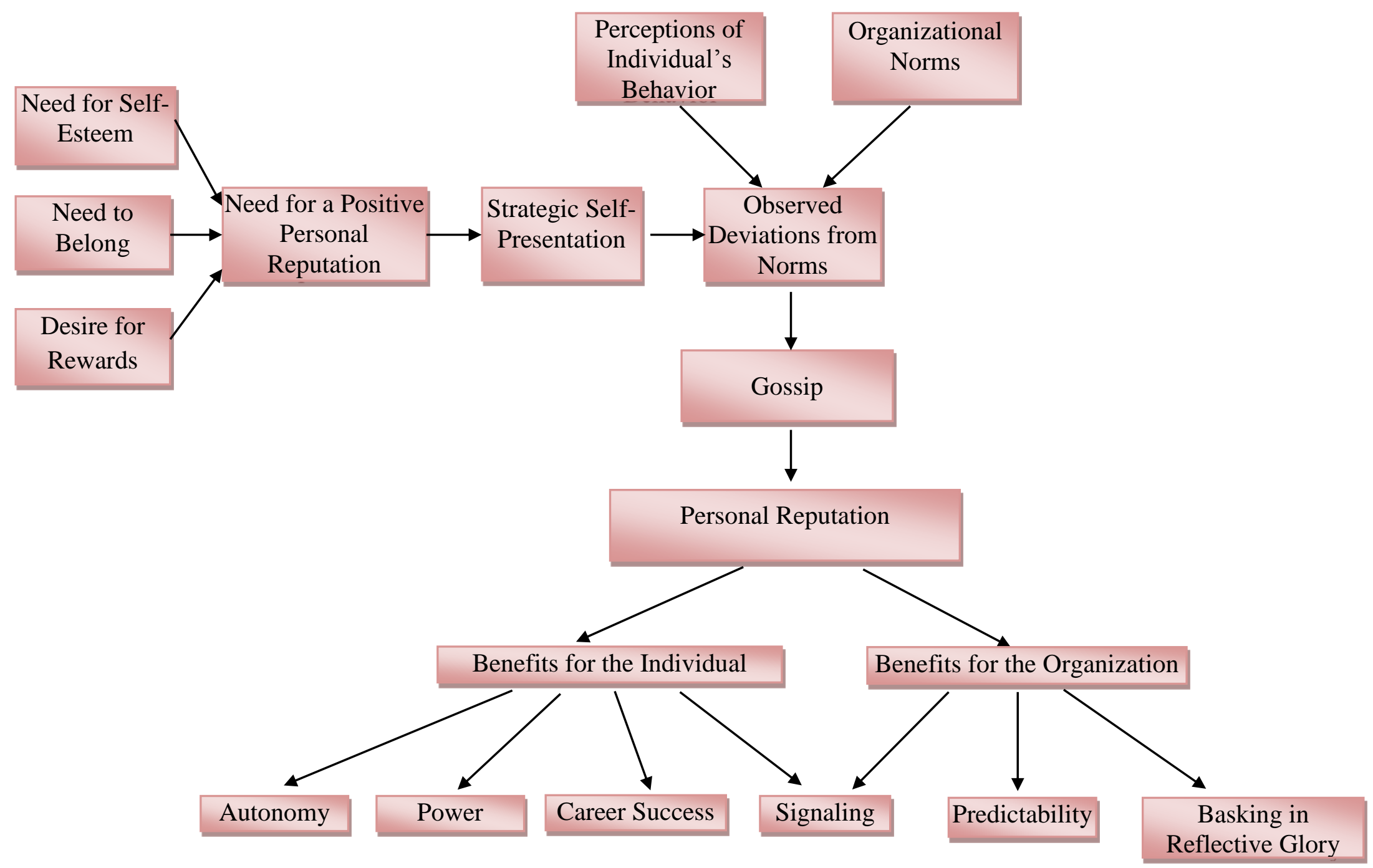

Figure 1. An Interactionist Model of Personal Reputation within Organizations 